\title{
IS VOTING IN GHANA ETHNICALLY BASED?
}

\section{Ransford Edward Van Gyampo, Tom Lodge and Ricky Appah}

\author{
Ransford Edward Van Gyampo is an Associate Professor of Political Science, \\ University of Ghana
}

Tom Lodge is Professor of Peace and Conflict Studies at the Department of Politics and Public Administration, University of Limerick

Ricky Appah is a PhD Candidate at the Department of Political Science,

University of Ghana

\begin{abstract}
Ghanaian scholars often argue that ethnicity is the leading factor shaping the electoral choices of voters in Ghana, and that voting in Ghana, like that of many other African countries, is ethnic-based. This paper seeks to test the validity of these perceptions. Voters in three key constituencies were selected and asked about considerations that shaped their voting preferences in Ghana's latest election in 2016. Their answers indicate a complicated mixture of motives which suggest that in areas believed to have been politically shaped by ethnic identities, voter choice is instrumental and rational, influenced more by bread and butter concerns than by ethnic loyalty.
\end{abstract}

Keywords: ethnicity, voting, rational choice, party identification, ideology, Ghana

\section{INTRODUCTION}

When Ghanaian voters make their electoral choices are they mainly influenced by ethnic identity? There is a powerful body of scholarship that helps to maintain this proposition. Voting and the composition of national government in many established democracies in the Western world are supposedly shaped by more rational issues of ideology, philosophies and policies (Arthur 2009). However, in many developing democracies it is chiefly identity-based concerns that reportedly direct voting behaviour. In Ghana itself the view that elections are principally ethnic-based is shared widely, as is the view that Ghanaian politics conforms to a pattern in which political life is moulded by affinities to ethnic groups (Chazan 1982; Frempong 2001; Nugent 2001; Oelbaum 2004; Asante 2006; Andrews \& Inman 2009; Norris Mattes 2003; Berman et al. 2004). 
Fridy (2007, p. 286) asserts that ethnicity appears to be 'extremely significant in Ghanaian elections and that its implication to the electoral outcome is of immense importance'. One explanation for this might be that ethnic mobilisation is a pragmatic choice for politicians in a setting in which particular ethnic groups dominate certain regions and constituencies in Ghana, and hence appeal to common ethnic ties to generate unified support (Bates 1974, p. 470, cited in Arthur, 2009; Lentz \& Nugent 2000).

Such support may not necessarily reflect fixed loyalties. Ghana's political history suggests that at different times different ethnic solidarities have successively predominated. Since independence in 1957, Ghana has witnessed as many as seven different political regimes, all of which had varying ethnic dispositions, right until the inception of the Fourth Republic in 1992. Running state machinery had moved from the southern Akan groups during the Nkrumah era, through the Ga-Ewe alliance under the National Liberation Council (NLC); the central Akan (Asante-Brong) alliance of Busia; the fairly balanced ethnic government of the National Redemption Council (NRC)/Supreme Military Council (SMC) assemblage; a minority accumulation with uneven northern representation within the Limann administration; and finally to a profoundly Ewe-based ruling faction within the Provisional National Defence Council (PNDC) (Chazan 1982, p. 461).

In seeking to clarify the ethno-political distribution within the Ghanaian electoral system, Amoah (2003) sought to expose the ethno-national patterns that emerged from the elections in 2000. He found strong suggestions that each vice-presidential candidate from the four leading political parties (the National Democratic Congress, (NDC) the New Patriotic Party (NPP), the Convention People's Party (CPP) and the Peoples National Convention (PNC)) should have originated from one of the three northern regions. His work uncovered the ethno-nationalistic sentiments that had beclouded some Ghanaians as a way of showing solidarity towards their ethnic groupings, rather than promoting a patriotic political nationalism beyond their ethnic cleavages.

Lentz and Nugent (2000) are less certain about the salience of ethnicity in Ghana's politics. At certain times, they note that ethnic tensions have manifested themselves, only to be followed by long periods when the importance of ethnicity is denied by virtually all sides.

Ethnic membership does seem to influence political appointments. The two leading political parties in Ghana, the NPP and the NDC, are ostensibly regarded as Asante/Akan and Ewe-based parties respectively (Gyimah-Boadi \& Asante 2006). Political appointments have been dominated by Asantes/Akans whenever the NPP is in power. Ewes and to some extent people from the northern regions of Ghana have also dominated the appointees during the NDC regimes. This pattern 
appears to confirm claims that the two parties are ethnically-based and hence derive their support from the ethnic groups that form their strongholds. Ghanaian scholars have also argued that electoral competition in Ghana only fuels anxiety and friction between Ewes and the Asantes (Frempong 2001; Gyimah-Boadi, 2001).

There are, however, other ways of understanding Ghanaian voting choices that are evident in the scholarship. Within Ghana there appears to be general academic agreement that ethnicity is the primary determinant in shaping voter choice; but studies by outsiders offer a more complex picture. Paul Nugent (2001), for example, does not discount the effects of ethnic bloc voting in certain regions but also argues that there are substantial groups of swing voters and that voters outside the bloc regions are also influenced by other considerations. Lindberg and Morrison (2008) believe that clientelism may be more important than ethnic identity; in other words that voters may support certain candidates in the expectation that they will be rewarded or protected in one way or another. Peter Arthur (2009) is also inclined to view a range of factors other than ethnic identity as determinants of choice. There has been a long tradition in Ghana of competing and distinct ideologies helping to shape the two bases of party politics that emerged during the Nkrumah/decolonisation era. These ideological strains have persisted, helping to configure the divide between the two main parties in Ghana (Fridy 2007). Hence the respective Asante/Akan and Ewe coalitions may have class-based and intellectual lineages helping to constitute them, not simple ethnic solidarity. There is, however, another reason for asking questions about ethnicity in Ghana's politics, quite aside from the variations in academic perceptions. In contemporary Ghana, batteries of interventions and programmes have been introduced to promote issue-based voting among the citizenry. These have been implemented by state bodies like the National Commission for Civic Education (NCCE) and other non-state institutions (Gyimah-Boadi 2008). Since 1992, there has been a rise and growth of strong civil society organisations such as the Institute of Economic Affairs (IEA-Ghana), IMANI-Ghana, Institute for Democratic Governance (IDEG), the Christian Council of Ghana (CCG), and the Centre for Democratic Development (CDD-Ghana). These bodies have undertaken massive and sustained voter education programmes with a view to informing and sensitising Ghanaians about the rational considerations that must inform their preferences in elections (NCCE, 2016; Gyimah-Boadi 2008).

In the lead-up to elections since 2000, several voter education programmes in Ghana have aimed at promoting rational voting (NCCE 2016; IEA 2017). These include the conduct of town hall meetings, presidential debates, and evening encounters with presidential aspirants before elections. Since 1992 the NCCE has carried out several voter education programmes to sensitise voters on what to look out for before voting. The CDD-Ghana, the CCG, and the IEA-Ghana, have all 
created platforms for a healthy contest of ideas, through debates, by presidential and parliamentary aspirants in the lead-up to elections in Ghana (Gyampo, 2011). It cannot be said that these interventions merely amounted to 'pouring water on stone'. Indeed, studies show that these interventions have had some impact on voting behaviour (Gyampo 2009; IEA 2017; Gyampo 2013; NCCE 2016).

Given this context it seems worthwhile to explore the possibility that growing numbers of Ghanaians are prompted by party identification and political ideology when they make their respective choices during elections.

\section{THEORETICAL MODELS OF VOTING}

This study is grounded in Andrew Heywood's four explanatory models for the way people make their voting decisions. Heywood (2000) listed party identification, sociological identity, rational choice and dominant ideology as the main factors that shape voter behaviour in any election. These are explained below and form the bases for analysing the empirical data or findings of the study.

\section{Party Identification Model}

In this model, attitude towards policies and leaders as well as perceptions about group and personal interests, tend to develop on the basis of party identification (Heywood 2000). This partisan alignment creates stability and continuity, especially in terms of the habitual patterns of voting behaviour. One weakness of this model is the growing evidence of partisan de-alignment (Green et al. 2002). In other words, people now prefer to vote not merely for the party but they also consider the quality of the candidates contesting an election on the party's ticket. In Ghana this has led to a phenomenon popularly referred to as 'skirt and blouse voting', which takes place when voters choose their party's presidential candidate but prefer a parliamentary candidate from a different political party. This is because the parliamentary candidate presented by their preferred party cannot serve their interests, and vice versa, and indicates a decline in party identification and habitual voting patterns, particularly among voters in developed democracies (ibid.).

\section{Sociological Model}

Rather than developing a psychological attachment to a party on the basis of family influence, the sociological model highlights the importance of social alignment, reflecting the various divisions and tensions within society. The most significant of these divisions is ethnicity. Other important considerations may 
include class, religion, gender and race. In simple terms, the theory states that people may vote for an aspirant if he or she belongs to their class, comes from their ethnic group, shares the same religious beliefs, etc.

This model has, however, been attacked on the grounds that voting to simply protect ethnic or religious interest may not necessarily advance the interests of voters in terms of ensuring the selection of the right calibre of people to lead them. There is also growing empirical evidence that the link between sociological factors and party support has weakened in modern societies.

The sociological model of voting has some shortcomings. In the first place, it is deficient in expounding the variations that take place in voting as a result of economic factors specific to each election. Although social factors may attempt to explain the long-term constancy of voting behaviour, they do not explicate the disparities in the behaviour of voters in different elections. In similar vein they do not explain why persons with an affinity to certain social groups vote in a manner expected of people belonging to different social groups (Antunes 2010). The model also fails to acknowledge the importance of individual policy preferences and the appraisal of government performance on voting.

\section{Rational Choice Model}

In this model, voting is seen as a rational act, in the sense that voters are believed to decide their party preference on the basis of personal interest (Heywood 2000). Rather than being habitual and a manifestation of broader attachments and allegiances, voting is seen as essentially instrumental: that is, as a means to an end (Popkin 1994). The rational choice model, which is usually associated with highly educated people, stresses the importance of 'issue voting', and suggests that parties can significantly influence their electoral performance by reshaping their policies. Erdmann (2007) is of the view that there is a considerable connection between the level of education and the quality of voter choice in elections. By implication, societies with high literacy rates are more likely to take into deeper consideration the consequences of their motive for the choice of a candidate than societies with lower literacy levels. It is generally accepted that one of the consequences of partisan and class dealignment has been the spread of issue voting. The weakness of this theory is that it removes the individual voter from his or her social and cultural context.

\section{Dominant Ideology Model}

This model stresses the importance of political ideology in influencing the behaviour of voters. The basic premise of the dominant ideology model is that: 
... there is in most class societies a pervasive set of beliefs that broadly serves the interest of the dominant class. This dominant ideology is then adopted by subordinate classes which are thereby prevented from formulating any effective opposition.

(Abercrombie \& Turner, 1978)

This model simply states that the dominant ideology influences voters (Heywood 2000). Consequently, if voters' attitudes conform to the tenets of a dominant ideology, parties would develop their policies in line with that ideology so as to gain voter support. The weakness of this ideology is that it removes individual calculation and personal autonomy from the equation. It implies that people are not willing to weigh the merits and demerits of policy options being presented to them. Only once a candidate or a policy conforms to their ideological persuasion would they support it (ibid.).

\section{METHODOLOGY}

This paper seeks to test the validity of the long-held and derogatory view that elections and voter behaviour in Ghana are influenced by ethnic considerations. Three main constituencies were selected to test this hypothesis, and the reasons for their choice are explained below. Within each constituency, purposive samples of respondents answered questions about the considerations that shaped their voting preferences in Ghana's most recent election in 2016.

The constituencies selected were the Ho West Constituency (HWC) in the Volta Region, the Manhyia South Constituency (MSC) in the Ashanti Region, and the Ayawaso West Wuogon Constituency (AWWC) in the Greater Accra Region. The HWC and the MSC are among those constituencies believed to vote overwhelmingly on ethnic lines for the NDC and NPP respectively (Gyimah-Boadi \& Debrah 2008; Frempong 2001; Arthur 2009).

The MSC is situated in the heart of the Kumasi metropolis, which is the capital of the Ashanti Region. Constituents in this area have since 1996 voted for the NPP in all general elections. For instance, in 1996 they voted 79.9\% for the NPP and only $18.7 \%$ for the NDC. In 2000 they voted $85.7 \%$ for the NPP and gave only $12 \%$ of their support to the NDC. Similarly, in 2016 they voted $86.2 \%$ for the NPP and gave $13.4 \%$ of their votes to the NDC. Table 1 below shows the full picture of the voting pattern. 
Table 1: Historical performance between NDC and NPP in Manhyia South

\begin{tabular}{|c|c|c|c|c|c|c|}
\hline Party & $\mathbf{1 9 9 6}$ & $\mathbf{2 0 0 0}$ & $\mathbf{2 0 0 4}$ & $\mathbf{2 0 0 8}$ & $\mathbf{2 0 1 2}$ & $\mathbf{2 0 1 6}$ \\
\hline NPP & $79.9 \%$ & $85.7 \%$ & $79.0 \%$ & $77 \%$ & $80.8 \%$ & $86.2 \%$ \\
\hline NDC & $18.7 \%$ & $12.0 \%$ & $20.0 \%$ & $21.9 \%$ & $18.8 \%$ & $13.4 \%$ \\
\hline
\end{tabular}

Source: Electoral Commission of Ghana

The HWC was selected for similar reasons as this constituency is also located in the capital of the Volta Region. Like the MSC, the HWC has since 1996 voted overwhelmingly for the NDC. In 1996 they voted 97.4\% for the NDC and 2.3\% for the NPP. In 2000, they voted close to $90 \%$ for the NDC and $5 \%$ for the NPP. In 2016, they voted $88.6 \%$ for the NDC and $10.3 \%$ for the NPP. Table 2 below gives the full detail of the voting trend.

Table 2: Historical performance between NDC and NPP in Ho West

\begin{tabular}{|c|c|c|c|c|c|c|}
\hline Party & $\mathbf{1 9 9 6}$ & $\mathbf{2 0 0 0}$ & $\mathbf{2 0 0 4}$ & $\mathbf{2 0 0 8}$ & $\mathbf{2 0 1 2}$ & $\mathbf{2 0 1 6}$ \\
\hline NPP & $2.3 \%$ & $5.0 \%$ & $10.1 \%$ & $7.9 \%$ & $7.4 \%$ & $10.3 \%$ \\
\hline NDC & $97.4 \%$ & $89.9 \%$ & $89.1 \%$ & $90.3 \%$ & $91.8 \%$ & $88.56 \%$ \\
\hline
\end{tabular}

Source: Electoral Commission of Ghana

Unlike the other two parties the AWWC cannot be labelled as a stronghold of any political party. Elections in this constituency are very competitive and either the two main parties could win but not by a large majority. For instance, in 1996 voters in the area gave $48.4 \%$ of their support to the NPP and $48.6 \%$ to the NDC. In 2012, they voted $49.1 \%$ for the NPP and $49.9 \%$ for the NDC. Similarly, in 2016 they voted $56.4 \%$ for the NPP and $42 \%$ for the NDC. Table 3 below provides more information about the voting pattern from 1996 to 2016.

Table 3: Historical performance between NDC and NPP in Ayawaso West Wuogon

\begin{tabular}{|c|c|c|c|c|c|c|}
\hline Party & $\mathbf{1 9 9 6}$ & $\mathbf{2 0 0 0}$ & $\mathbf{2 0 0 4}$ & $\mathbf{2 0 0 8}$ & $\mathbf{2 0 1 2}$ & $\mathbf{2 0 1 6}$ \\
\hline NPP & $48.4 \%$ & $58.0 \%$ & $54.8 \%$ & $48.7 \%$ & $49.1 \%$ & $56.45 \%$ \\
\hline NDC & $48.6 \%$ & $37.6 \%$ & $43.4 \%$ & $48.6 \%$ & $49.9 \%$ & $42.05 \%$ \\
\hline
\end{tabular}

Source: Electoral Commission of Ghana 
The AWWC was selected primarily because it is situated in the Greater Accra Region (a swing region) and also because the constituency is recognised as a cosmopolitan community with people from diverse ethnic, educational, religious and economic backgrounds. More importantly, most people in the AWWC are highly educated; it is appropriate to test whether even the highly educated also vote on ethnic grounds, given the seeming prevalence of ethnicity as the main factor that shapes voting. If ethnicity is indeed a determinant of voting among Ghanaians, it should not be confined to areas that are supposedly known to vote on ethnic lines. It should spread to even cosmopolitan constituencies, hence the selection of the third constituency as a test case.

The target population for the study comprised respondents aged 18 years and above at the time when the 2016 general elections were organised. ${ }^{1}$ The population of AWWC was 65 000; that of the HWC was 62000 while the MSC had 68000 as their population (Electoral Commission 2016). Through the purposive sampling technique, 110 respondents were sampled from the three constituencies as follows:

- Forty (40) respondents from the MSC of which twenty (20) were cardbearing members of the NPP and the other twenty (20) comprised voters who were not necessarily supporters of the NPP. The reason for this mode of selection was that it was also desirable to know whether there existed any difference in the voting pattern between card-bearing members (supporters) of the NPP and those who did not have evidence of support for the NPP within the constituency. Also, twenty (20) out of the forty (40) respondents were men and the other twenty (20) were women. This was to establish whether any difference existed in the pattern of voting among the genders. The same process was repeated in the HWC.

- Thirty (30) respondents were interviewed from the AWWC of which ten (10) were card-bearing members of the NPP, ten (10) were cardbearing members of the NDC, and the other ten (10) respondents were neutral and had no formal evidence of affiliation with any political party. The justification for this choice of sampling was because the study sought to identify any difference in the voting pattern among these groups of respondents. Additionally, fifteen (15) out of the thirty (30) respondents were males and the other fifteen (15) were females simply because the study intended to establish whether there existed any difference in the pattern of voting among the genders.

1 The 2016 election was Ghana's last general election at the time of conducting this research. 
Using a planned set of semi-structured or open-ended questions, the study deployed a central question that guided conversational interviews and interactions with the selected respondents. The central question was whether voting patterns in Ghana could still be described as ethnic-based in spite of the giant strides made in voter education and democratic consolidation. This form of qualitative approach was useful as it also provided the grounds for respondents to express their views about other issues without undue restrictions. In asking questions the researcher was careful to use phraseology that did not imply a value-laden view of ethnically motivated voting. For example, the researcher did not suggest in his interactions with respondents that ethnic voting was irrational and that ideologically or programmatically-based party identification was more rational.

\section{RESULTS OF STUDY}

\section{Gender Distribution of Respondents}

Out of the total sample size of 110 voters from the three study areas of MSC, HWC and AWWC, fifty-five (55) of the respondents (representing 50\%) were males while the remaining were females, implying that the selection of respondents was evenly distributed between males and females. It must be noted from the outset that gender differences in this study had no correlation with the determinants of voting. As Heywood (2000) has observed, the models or theories of voting are not gender-sensitive.

\section{Educational Background of Voters}

Among the interviewees from the MSC, 35\% (14 respondents) had obtained a basic education followed by $30 \%$ (12 respondents) with secondary level education. Six people $(15 \%)$ had university education; one person $(2.5 \%)$ had teacher training certificate while $17.5 \%$ (7 people) had no formal education. In the HWC, 30.5\% (12 respondents) had obtained secondary education. Those with basic level education came second with $25.5 \%$ (11 respondents), followed by those with no formal education $25 \%$ (10 respondents). Those with university education had a representation of $12.5 \%$ (6 respondents) and finally, those with teacher training education or a related certificate represented $2.5 \%$ (1 person). In the AWWC, $43.3 \%$ (13 respondents) had acquired secondary education. Those with basic education constituted $23.3 \%$ (7 respondents) of the population while $16.7 \%$ had university education. Ten (10\%) were trained teachers while $6.7 \%$ had no formal education. These proportions compare reasonably closely to the generalised distribution of access to education in Ghana, though the samples included rather larger percentages of university graduates. This is borne out by the representative sample of Ghanaians who participated in the 2016/2018 Afrobarometer survey, 
which broke down into the following educational categories: no formal schooling, $15.3 \%$; basic education, $27 \%$; secondary schooling, $43 \%$; and post-secondary, $14 \%$.

Table 4: Distribution of respondents by level of education

\begin{tabular}{|l|c|c|c|r|r|c|}
\hline \multirow{2}{*}{$\begin{array}{l}\text { Level of } \\
\text { Education }\end{array}$} & \multicolumn{3}{|c|}{ Frequency } & \multicolumn{3}{c|}{ Percentage } \\
\cline { 2 - 7 } & $\begin{array}{c}\text { Manhyia } \\
\text { South }\end{array}$ & $\begin{array}{c}\text { Ho } \\
\text { West }\end{array}$ & $\begin{array}{c}\text { Ayawaso } \\
\text { West } \\
\text { Wuogon }\end{array}$ & $\begin{array}{c}\text { Manhyia } \\
\text { South }\end{array}$ & $\begin{array}{c}\text { Ho } \\
\text { West }\end{array}$ & $\begin{array}{c}\text { Ayawaso } \\
\text { West } \\
\text { Wuogon }\end{array}$ \\
\hline None & 7 & 10 & 2 & 17.5 & 25 & 6.7 \\
\hline Basic Education & 14 & 11 & 7 & 35.0 & 25.5 & 23.3 \\
\hline Secondary Education & 12 & 12 & 13 & 30.0 & 30.5 & 43.3 \\
\hline Teacher Training & 1 & 2 & 3 & 2.5 & 5 & 10 \\
\hline University/ Polytechnic & 6 & 5 & 5 & 15.0 & 12.5 & 16.7 \\
\hline
\end{tabular}

Source: Field data (2017)

\section{Voting Frequency}

The study shows that voters in the three constituencies had all voted previously in elections conducted in Ghana. Even though some respondents had voted only once since 1992, others had voted in all seven elections conducted in Ghana. For instance, in the MSC, $3(7.5 \%)$ of the respondents claimed to have voted only once in their lifetime since 1992. However, $6(15 \%)$ of the respondents had voted in all seven elections held in Ghana. Most of the respondents in all three constituencies had voted at least thrice in their life time, as illustrated in Table 5 below.

Table 5: Distribution of respondents by number of times voted

\begin{tabular}{|l|c|c|c|c|c|c|}
\hline \multirow{2}{*}{$\begin{array}{l}\text { Number of times } \\
\text { voted }\end{array}$} & \multicolumn{3}{|c|}{ Frequency } & \multicolumn{3}{c|}{ Percentage } \\
\cline { 2 - 7 } & $\begin{array}{c}\text { Manhyia } \\
\text { South }\end{array}$ & $\begin{array}{c}\text { Ho } \\
\text { West }\end{array}$ & $\begin{array}{c}\text { Ayawaso } \\
\text { West } \\
\text { Wuogon }\end{array}$ & $\begin{array}{c}\text { Manhyia } \\
\text { South }\end{array}$ & $\begin{array}{c}\text { Ho } \\
\text { West }\end{array}$ & $\begin{array}{c}\text { Ayawaso } \\
\text { West } \\
\text { Wuogon }\end{array}$ \\
\hline Once & 3 & 2 & 3 & 7.5 & 5.0 & 10.0 \\
\hline Two times & 8 & 9 & 8 & 20.0 & 22.5 & 26.7 \\
\hline Three times & 7 & 10 & 9 & 17.5 & 25.0 & 30.0 \\
\hline Four times & 2 & 3 & 4 & 5.0 & 7.5 & 13.3 \\
\hline Five times & 11 & 7 & 3 & 27.5 & 17.5 & 10.0 \\
\hline Six times & 3 & 5 & 1 & 7.5 & 12.5 & 3.3 \\
\hline Seven times & 6 & 4 & 2 & 15.0 & 10.0 & 6.7 \\
\hline
\end{tabular}




\section{Party Affiliation}

In line with the methodology of the study, $50 \%$ of the respondents selected in the MSC were card-bearing members of political parties while $50 \%$ had no party affiliation. The same outcome can be said of the HWC and the AWWC. For instance, of the 40 respondents in the MSC, 20 were card bearing members of a political party while 20 claimed they had no affiliation to any political party. Similarly, of the 30 respondents from the AWWC, 15 were party members while 15 had no affiliation with any party. See Table 6 below for details:

\section{Table 6: Distribution of respondents by their affiliation with a political party}

\begin{tabular}{|l|c|c|c|c|c|c|}
\hline \multirow{2}{*}{ Type of voter } & \multicolumn{3}{|c|}{ Frequency } & \multicolumn{3}{c|}{ Percentage } \\
\cline { 2 - 7 } & $\begin{array}{c}\text { Manhyia } \\
\text { South }\end{array}$ & Ho West & $\begin{array}{c}\text { Ayawaso } \\
\text { West } \\
\text { Wuogon }\end{array}$ & $\begin{array}{c}\text { Manhyia } \\
\text { South }\end{array}$ & Ho West & $\begin{array}{c}\text { Ayawaso } \\
\text { West } \\
\text { Wuogon }\end{array}$ \\
\hline Party member & 20 & 20 & 15 & 50 & 50 & 50 \\
\hline $\begin{array}{l}\text { Not a party } \\
\text { member }\end{array}$ & 20 & 20 & 15 & 50 & 50 & 50 \\
\hline
\end{tabular}

Source: Field data (2017)

\section{Knowledge of Ethnic-Based Voting}

Most of the respondents knew what ethnic-based voting was, or at least had an idea of the incidence of ethnic-based voting. In the MSC these constituted 84\% while in the HWC they accounted for $91 \%$ of the respondents. In the AWWC all 30 respondents were aware of ethnic-based voting in Ghana's politics. Findings from the study also revealed that all the respondents who had knowledge about the incidence of ethnic-based voting accepted that it is a form of voting where the voter's decision on how to vote is influenced by his or her ethnic affinity with the candidate rather than by policy considerations or the competence of the candidate. One respondent from MSC, for example, stated that ethnic-based voting '... is when people vote for politicians because they share a common ethnic background'. Another participant from HWC stated that 'Ethnic-based voting occurs when a person's desire to vote is influenced by the ethnic relations $\mathrm{s} / \mathrm{he}$ shares with the contestant vying for political power'.

It is, therefore, safe to establish that the conceptual phase of ethnic-based voting equally implies voting based on the ethnic background of the candidate and the ethnic outlook of the political party. More precisely for these informants, 
ethnic-based voting 'is defined relative to both party flag bearer and the party itself' (Arthur 2009, p. 47).

\section{Determinants of Voting in Ghana}

The empirical findings of this study indicate that even though respondents had previously been influenced by ethnic considerations in voting, that situation may be changing. Certainly, in the MSC 8 (20\%) of the 40 respondents consented that sociological factors, particularly ethnic attachments, influenced their decision in the 2016 general elections. But as many as $24(60 \%)$ of the respondents asserted that they voted for the NPP because of their belief in the competence of the flag bearer of the party and the sound policy prescriptions encapsulated in the NPP manifesto. The remaining $8(20 \%)$ respondents also voted for the NPP because of their loyalty to the party. One respondent expressed it thus:

[...] when elections in the Fourth Republic commenced, I used to vote for the NPP because I am an Ashanti and I felt more comfortable voting for the party because I perceived it to be a party for only Asante. As times went by, I realised that the New Patriotic Party was not made up of only the Akan or Asante but rather, people from all sort of ethnic backgrounds and that I was misled by the political propaganda of the day. In addition, the Ashanti Region is now seen to be infiltrated by people from all the regions of the country who equally support the NPP strongly. I, therefore, had to realign my intentions for voting so as to benefit from the choice I make and to help the democratic development of the nation.

So in this case party identification appears to be the guiding impulse.

Similarly, in the HWC $6(15 \%)$ of the respondents voted on ethnic grounds while $26(65 \%)$ of the respondents voted because of rational factors such as competence, capability and track record. Eight (20\%) respondents voted for the NDC because of their loyalty to the party.

In the AWWC, 2 (6.7\%) respondents voted on ethnic grounds in the 2016 elections and $2(6.7 \%)$ respondents voted because of their loyalty to the parties they voted for. But as many as $26(86.6 \%)$ respondents voted because of the performance of the government of the day, as well as the accomplishments or track record of candidates. One respondent explicitly stated that:

When I started voting, the direction of my vote was influenced by my family, but after a while when I became more independent, I began 
to look at the capabilities of the candidates before I decided on where my vote should go $[. .$.

From the above, it may be argued that ethnicity may have played a key role in shaping voter behaviour in the past, and may still play some role in determining voting among a segment of the voter population in fledgling democracies. However, evidence from respondents who voted in the 2016 elections suggests the considerable influence of rational choice in guiding voter behaviour among the people sampled for the study in the respective constituencies. It is plausible to argue that in spite of the ostensibly ethnic constitution of the political parties' core support, ethnicity may no longer be the key determining factor of voting, even in core areas such as the HWC and MSC constituencies. A range of circumstances may have helped to alter the considerations affecting voter behaviour, including urbanisation and the kinds of social mobility described in one of the interviews as infiltration. Another key factor may indeed be the efforts all over Ghana to institutionalise democracy through a series of voter education programmes. Respondents in the interviews often referred to the work of these programmes.

The electoral performance of a political party in a region may not be adequate to describe the voting pattern of the people there as being ethnically based, as is shown by the study. Between 1992 and 2012 the Ashanti and Volta regions demonstrated massive support for the NPP and NDC respectively. For instance, the electoral outcome of the 1992 presidential race shows that while the NDC in the Volta Region led by J.J. Rawlings (whose mother also hailed from the Volta Region) acquired $93.2 \%$ of the votes, the NPP, whose frontrunner was Albert Adu Boahen, obtained only $3.6 \%$ of the valid vote cast. The results were reversed in the Ashanti Region, where the leader of the NPP Albert Adu Boahen received $60.5 \%$ of the votes cast while Rawlings had $32.9 \%$; see Table 7 below.

Table 7: Results of the 1992 presidential election

\begin{tabular}{|l|c|c|c|c|}
\hline Region & $\begin{array}{c}\text { Turnout } \\
(\boldsymbol{\%})\end{array}$ & $\begin{array}{c}\text { Total Votes } \\
\text { Cast }\end{array}$ & $\begin{array}{c}\text { Rawlings } \\
\text { (NDC) } \\
\text { Vote (\%) }\end{array}$ & $\begin{array}{c}\text { Adu-Boahen } \\
\text { (NPP) } \\
\text { Vote (\%) }\end{array}$ \\
\hline Ashanti & 50.05 & 732990 & 32.9 & 60.5 \\
\hline Volta & 62.4 & 491551 & 93.2 & 3.6 \\
\hline
\end{tabular}

Source: Electoral Commission of Ghana, 1992

The findings in the 1996 election were not different from that of 1992 as Rawlings gained $94.5 \%$ of the valid votes cast in the Volta Region and John Kufuor (the 
leader of the NPP) also received $4.7 \%$. In the Ashanti Region, on the other hand, Kufuor came up with $65.8 \%$ of the votes, whilst Rawlings obtained $32.8 \%$ of the votes; see Table 8 below.

Table 8: Results of the 1996 presidential election

\begin{tabular}{|l|c|c|c|c|}
\hline Region & $\begin{array}{c}\text { Turnout } \\
(\%)\end{array}$ & $\begin{array}{c}\text { Total Votes } \\
\text { Cast }\end{array}$ & $\begin{array}{c}\text { Rawlings } \\
\text { (NDC) } \\
\text { Vote (\%) }\end{array}$ & $\begin{array}{c}\text { Kufuor } \\
\text { (NPP) } \\
\text { Vote (\%) }\end{array}$ \\
\hline Ashanti & 79.8 & 1258032 & 32.8 & 65.8 \\
\hline Volta & 81.8 & 730251 & 94.5 & 4.7 \\
\hline
\end{tabular}

Source: Electoral Commission of Ghana, 1996

Voting trends in the 2000 and 2004 elections were no different from those of previous elections, although the founder and leader of the NDC had retired after successfully serving his constitutionally-mandated two terms as president of Ghana. The flag bearer of the NDC, Atta Mills, whose lineage hailed from the Central Region, maintained a firm control of the Volta Region with $86.81 \%$ of votes whilst Kufuor came up with only $6.64 \%$ of the valid vote cast. In the Ashanti Region on the other hand, while Kufuor obtained $75.56 \%$ of the valid votes cast, Atta Mills received 22.73\%. Table 9 below illustrates the point.

Table 9: Results of the 2000 presidential election

\begin{tabular}{|l|c|c|c|c|}
\hline Region & $\begin{array}{c}\text { Turnout } \\
(\boldsymbol{\%})\end{array}$ & $\begin{array}{c}\text { Total Votes } \\
\text { Cast }\end{array}$ & $\begin{array}{c}\text { Atta Mills } \\
\text { (NDC) } \\
\text { Vote (\%) }\end{array}$ & $\begin{array}{c}\text { Kufuor } \\
\text { (NPP) } \\
\text { Vote (\%) }\end{array}$ \\
\hline Ashanti & 88.7 & 1655760 & 24.0 & 74.6 \\
\hline Volta & 87.6 & 705827 & 83.8 & 14.2 \\
\hline
\end{tabular}

Source: Electoral Commission of Ghana, 2000

The 2004 elections followed a similar trend to the previous elections as Kufuor won in the Ashanti Region by $74.6 \%$ of the valid votes cast and Atta Mills received $24 \%$. In the Volta Region, on the other hand, Atta Mills won by $83.3 \%$ and Kufuor received $14.2 \%$ of the votes. In the 2008 general elections, the NPP presented a new candidate in the person of Nana Akufo-Addo as a successor to Kufuor, who had successfully completed his two-term constitutional mandate as president of the 
Republic of Ghana. The NDC, on the other hand, maintained their presidential candidate who had stood in both the 2000 and 2004 elections. In the end, Atta Mills won the Volta Region with $82.88 \%$ while Akufo-Addo received $14.98 \%$ of the votes. In the Ashanti Region, on the other hand, Akufo-Addo won by $72.4 \%$ while Atta Mills received 26.1\% of the vote (see Table 10 ).

Table 10: Results of the 2008 presidential election

\begin{tabular}{|l|c|c|c|c|}
\hline Region & $\begin{array}{c}\text { Turnout } \\
(\%)\end{array}$ & $\begin{array}{c}\text { Total Votes } \\
\text { Cast }\end{array}$ & $\begin{array}{c}\text { Atta Mills } \\
\text { (NDC) } \\
\text { Vote (\%) }\end{array}$ & $\begin{array}{c}\text { Akufo-Addo } \\
\text { (NPP) } \\
\text { Vote (\%) }\end{array}$ \\
\hline Ashanti & 79.7 & 1270844 & 26.1 & 72.4 \\
\hline Volta & 81.8 & 733938 & 82.28 & 14.98 \\
\hline
\end{tabular}

Source: Electoral Commission of Ghana, 2008

By 2012, two presidents had completed their constitutionally-mandated terms. President Mills, the third sitting president, died in office and his vice president, John Mahama, was sworn into office to complete the remaining term of the late president. Going into the 2012 elections, the NPP maintained their presidential candidate of 2008 whilst the NDC presented John Mahama as their candidate. That notwithstanding, the pattern of voting between the two regions was not altered. Whereas Akufo-Addo won with $70.86 \%$ of the total valid vote cast in the Ashanti Region, Mahama secured 28.35\% of the votes. In the Volta Region, on the other hand, Mahama won with $85.47 \%$ of the votes but Akufo-Addo received only $12.93 \%$ of the votes (see Table 11 ).

Table 11: Results of the 2012 presidential election

\begin{tabular}{|l|c|c|c|c|}
\hline \multicolumn{1}{|c|}{ Region } & $\begin{array}{c}\text { Turnout } \\
\mathbf{( \% )}\end{array}$ & $\begin{array}{c}\text { Total Votes } \\
\text { Cast }\end{array}$ & $\begin{array}{c}\text { John Mahama } \\
\text { (NDC) } \\
\text { Vote (\%) }\end{array}$ & $\begin{array}{c}\text { Akufo-Addo } \\
\text { (NPP) } \\
\text { Vote (\%) }\end{array}$ \\
\hline Ashanti & 80.3 & 1572361 & 28.35 & 70.86 \\
\hline Volta & 82.4 & 1090007 & 85.47 & 12.93 \\
\hline
\end{tabular}

Source: Electoral Commission of Ghana, 2012

Even though the voting patterns may suggest the influence of ethnicity, two main objections may be raised. First, Atta Mills and John Mahama did not hail from the Volta Region yet they continued to receive massive support from the area. 
Secondly, no empirical study had been conducted to interrogate what actually shapes the voting behaviour of people in the regions that were supposedly voting on ethnic lines. So, these historic patterns once again appear to confirm the salience of the party identification model in explaining decision-making among Ghana's voters.

That ethnicity has an influence in the electoral process of Ghana's politics remains likely. However, judging from this study, ethnicity is not sufficiently important to warrant its description as the topmost variable to influence voting in Ghana. A thorough analysis of the election results from 1992 to 2012 shows that the strength of the NDC and NPP in their strongholds is diminishing. In general, and with reference to Heywood's explanatory models, the evidence suggests that Ghanaian voting conforms less to the sociological model and that the party identification model is more relevant. This is hardly surprising, given that at present the two predominant political parties in Ghana have had a longer history than any of their predecessors. Rational choice may be more relevant in determining voter decisions in the more localised settings but more research would be needed to establish this.

It needs to be noted that on the whole the language used by respondents did not imply strong disapproval of ethnic loyalty or ethnic identity. Indeed, it is evident that some respondents had no hesitation in reporting the influence of ethnic considerations in the past, while substantial numbers still retained ethnic attachments and were not defensive in speaking about them. This is important as one methodological objection to our findings is that they may have been shaped by respondents' perceptions that ethnic voting is often perceived derogatively.

\section{INSTITUTIONALISING RATIONAL VOTING AMONG GHANAIANS}

Nearly all the respondents in the three constituencies sampled agreed on the need for voting to be based on programmatic issues and factors that shape national development. They highlighted the impact of interventions such as voter education and other debate platforms that force the discussion of issues to the forefront of public discourse in the leadup to elections. In the AWWC for instance, as many as 28 of the 30 respondents identified the conduct of presidential debates prior to elections in Ghana as one key intervention that influenced people to vote on policy issues rather than ethnicity or party identification. In the MSC, 18 respondents indicated the role of the NCCE in reducing ethnic voting and promoting voter decision based on fundamental bread and butter issues. Twenty-two respondents also pointed to town hall meetings and debates as key to institutionalising more issue-based voting. One respondent observed that: 'We liked and voted for the president and the ruling party because of their policy position on education 
which was highlighted during the various debates'. Among voters in the HWC, 33 respondents highlighted the crucial role of key interventions such as debates and other voter education programmes undertaken by civil society and the NCCE, prior to elections, in promoting the exercise of rational choice during voting. These responses attest to the impact of key initiatives and interventions of voter education in reducing ethnic voting and promoting the exercise of rational choice in deciding who should lead the Ghanaian people. In effect, even though ethnic cleavages may still exist and may have shaped voting patterns among some Ghanaians in the past, the current situation cannot be described as the same. This is particularly true during Ghana's 2016 elections which saw key democracy-enhancing voter education programmes by civil society and other state agencies evolve in Ghana.

\section{CONCLUSION}

Since 1992 when Ghana's fourth attempt at constitutional democracy commenced, seven consecutive general elections have been conducted. These elections have generally been described as free, fair, peaceful and transparent. However, what appears to be a dent on the nation's democratic credentials has been the view that voting as well as electoral outcomes have been shaped by ethnic considerations. This paper holds a dissenting view and challenges the long-held position that Ghanaian voters cast their ballots under the influence of their ethnic cleavages. Elections and voting in contemporary times in Ghana can no longer be simply described as ethnic consensus.

This study indicates that ethnic considerations may no longer be the overarching factors that shape voter behaviour in Ghana. Admittedly, the limited sample of the paper may not be adequate for an accurate representation of the factors that shape voting patterns in Ghana. It must, however, be noted that the results of Ghana's 2016 presidential elections clearly indicate that the choices of Ghanaian voters are shaped by party loyalty, programmatic ideology and instrumental concerns rather than simply by affective identity. Ghanaian elections are not ethnic competitions. Indeed, in the 2016 presidential elections, the sitting president of the ruling NDC lost to the opposition NPP by an unprecedented landslide margin of $44.4 \%$ to $53.85 \%$ (Electoral Commission, 2016). In addition, the NDC lost in as many as six out of the ten regions of Ghana, including the swing regions of Greater Accra, Central and Brong Ahafo. The electoral outcome of the 2016 elections could thus not have been only because of the ethnic preferences of voters, and it is obvious that other considerations determined the choice of Ghanaians. 


\section{----- REFERENCES}

Abercrombie, N \& Turner, B 1978, 'The dominant ideology thesis', The British Journal of Sociology, vol. 29, no. 2, pp. 149-170.

Amoah, M 2003, 'Nationalism in Africa: Ghana's presidential elections', Review of African Political Economy, vol. 30, no. 95, pp. 149-156. Retrieved 3 August 2016 from Jstor http://www.jstor.org/stable/4006749

Andrews, J \& Inman, K 2009, 'Explaining vote choice in Africa's emerging democracies', University of California, Irvine.

Antunes, R 2010, 'Theoretical models of voting behaviour', Exedra, vol. 4, pp. 145-170. Arthur, P 2009, 'Ethnicity and electoral politics in Ghana's Fourth Republic', Africa Today, vol. 56, no. 2, pp. 45-73.

Asante, R 2006, 'Local factors that shaped the 2004 general elections in the Ejura Sekyedumase, Mampong \& Effiduase-Asokore Constituencies', in Kwame Boafo-Arthur (ed.)

Voting for democracy in Ghana - 2004 elections in perspective, p. 136, Freedom Publications, Accra.

Bates, R 1974, 'Ethnic competition and modernization in contemporary Africa', Comparative Political Studies, vol. 6, no. 4, pp. 457-484.

Chazan, N 1982, 'Ethnicity and Politics in Ghana', Political Science Quarterly, vol. 97, no. 3, pp. 461-485.

Electoral Commission of Ghana 2005, Elections 2004: Ghana's parliamentary and presidential elections, Electoral Commission and Friedrich Ebert Foundation, Accra.

Electoral Commission of Ghana 2016, Election results, Electoral Commission of Ghana, http://www.ec.gov.gh/, (accessed on 12-01-17)

Erdmann, G 2007, The cleavage model, ethnicity and voter alignment in Africa: Conceptual and methodological problems revisited, German Institute of Global and Area Studies, Hamburg.

Frempong, AKD 2001, 'Ghana's election 2000: The ethnic undercurrent', Deepening Democracy in Ghana, vol 1, pp. 141-159.

Fridy, K 2007, 'The elephant, umbrella, and quarrelling cocks: Disaggregating partisanship in Ghana's fourth republic', African Affairs, vol. 106, no. 423, pp. 281-305.

Ghana 1992, Constitution of the Republic of Ghana, Ghana Publishing Corporation, Accra.

Ghana 2014, 2010 population and housing census: District analytical report, Ghana Statistical Service, Accra.

Ghana National Commission for Civic Education 2016, Survey report, NCCE, Accra. Green, D, Palmquist, B \& Schickler, E 2002, Partisan hearts \& minds: Political parties and the social identities of voters, Yale University Press, New Haven. 
Gyampo, REV 2009, 'Presidential debates and electoral fortunes of political parties in Ghana's 2008 elections', Politikon, vol, 36, no. 3, pp. 445-461.

Gyampo, REV 2013, 'Americanization of African politics: The case of Ghana's 2012 presidential debate series', Legon Journal of International Affairs and Diplomacy (LEJIAD), vol. 17, no. 1, pp. 67-92.

Gyimah-Boadi, E 2001, 'The December 2000 elections and prospects for democratic consolidation', in J Ayee (ed.), Deepening democracy in Ghana: Politics of the 2000 elections, vol. 1, p. 63, Freedom Publications, Accra.

Gyimah-Boadi, E \& Asante, R 2006, 'Ethnic structure, inequality and public sector governance in Ghana', in Y Bangura (ed.), Ethnic inequalities and public sector governance, Palgrave Macmillan, New York.

Gyimah-Boadi, E 2008, Ghana's Fourth Republic: Championing the African democratic renaissance?' Ghana Center for Democratic Development (CDDGHANA) Briefing Paper, vol. 8, no. 4, pp. 56-74.

Gyimah-Boadi, E \& Debrah, E 2008, 'Political parties and party politics in Ghana: governance in the Fourth Republic', Ghana Centre for Democratic Development, Accra.

Heywood, A 2000, Politics, Palgrave Macmillan, London.

Institute of Economic Affairs (Ghana) 2017, Impact of presidential debates in Ghana, IEA, Accra.

Lentz, C \& Nugent, P 2000, Ethnicity in Ghana: The limits of invention, Palgrave Macmillan, London.

Lindberg, S \& Morrison, M 2008, 'Are African voters really ethnic or clientelistic? Survey evidence from Ghana', Political Science Quarterly, vol. 123, no. 1, pp. 95-122.

Norris, P \& Mattes, R 2003, 'Does ethnicity determine support for the governing party?', Afrobarometer, vol. 26.

Nugent, P 2001, 'Ethnicity as an explanatory factor in the Ghana 2000 elections', African Issues, vol. 29, nos. 1-2, pp. 2-7.

Oelbaum, J 2004, 'Ethnicity adjusted? Economic reform, elections and tribalism in Ghana's Fourth Republic', Commonwealth E Comparative Politics vol. 42, no. 2, pp. 242-273.

Popkin, S 1994, The reasoning voter: Communication and persuasion in presidential campaigns, (2nd ed.), University of Chicago Press, Chicago. 